\title{
Fear of War among Newspaper Readers: A Study of Pulwama Incident
}

\author{
Nimra Gul ${ }^{1}$, Sajjad $\mathrm{Ali}^{2}$, Faiza Latif ${ }^{3} \&$ Fazal Rahim Khan ${ }^{4}$ \\ ${ }^{1}$ MS Scholar, Department of Arts \& Media, Foundation University, Rawalpindi Campus, Pakistan \\ ${ }^{2}$ Assistant Professor, Department of Journalism \& Mass Communication, University of Malakand, KP, Pakistan \\ ${ }^{3}$ Assistant Professor, Department of Mass Communications, Lahore College for Women University, Pakistan \\ ${ }^{4}$ Dean Faculty, Arts \& Social Sciences, Foundation University Islamabad, Rawalpind Campus, Pakistan \\ Correspondence: Sajjad Ali, Assistant Professor Department of Journalism \& Mass Communication, University \\ of Malakand, KP, Pakistan. E-mail: sajjadjmc@uom.edu.pk
}

Received: May 6, 2020

Accepted: May 18, 2020

Online Published: June 12, 2020

doi:10.5539/ass.v16n7p30

URL: https://doi.org/10.5539/ass.v16n7p30

\begin{abstract}
The aim of this research was to find out relationship between newspaper readers fear effects and Pulwama incident. The rationale behind the selection of topic was to measure the level of fear of war at the time of crisis between two countries. This study is based on quantitative methodology, whereas, survey research method was applied. For the data collection, the researcher applied questionnaire comprises 23 closed-ended questions from 50 respondents through purposive sampling method. The results revealed that both newspapers covered the issue, which spread fear of war among them due to repeatedly news stories, blaming contents, over presentation, exaggeration, LOC war like situation, biased and manipulated information. The correlation findings supported the hypotheses significantly that there is association between fear of war and newspaper reading.
\end{abstract}

Keywords: Fear of War, Newspaper Readers, Pulwama Incident, Daily Dawn, Daily Jang

\section{Introduction}

The level of fear due to media is also focused by Potter through some fear effects which have been discussed above. The effects of attack can be based on reality if the media shows the actual situations and happenings of various events in accordance to the actions taken by both countries to come up with a unified solution in order to make the relations better. Therefore, media whether print or electronic just focuses on spreading fear and terror among the civilians as an impact of this incident just for the sake of views and cultivate the thinking approach of people regarding the incident of Pulwama Attack.

This study will helps to analyze the relationship between the exposures to the Pulwama stories in mass media that is newspaper in context of the fear of war among the readers. However, many studies are not available on the Pulwama attack and the impact of mass media on the perception of reader and creation of fear of war among them.

Fear effect can be defined as the feeling of terror and anxiety that is induced by a person or a group of people in order to terrify the victim (Tuan, 2013). Fear effect is commonly developed by the media through fabricating the information which helps media to attract maximum viewers. This can be analyzed by the cultivation theory in which the information is cultivated and constructed that its meaning loses its originality. In case of Pulwama incident it has been observed that the social media, TV and newspapers implemented cultivation theory and fabricated the information in order to increase their viewers. This resulted into generation of fear effect among the viewers. In addition to that, this also leads towards the chaos and terror among civilians within Pakistan. According to Porter (2014), the media has an extensive influence either positive and negative on the audience which shows how media generally manipulates the audience which can be seen in the case of Pulwama attack that how the media (electronic and printed) manipulated civilians regarding the consequences in the form of a war between Pakistan and India leading towards various critical impacts on civilians specifically.

\subsection{Statement of Problem}

The research is focused on the similarities and differences of the perceptions of readers about the effects of fear among the readers of newspapers after the incidence of Pulwama in Indian Administered Kashmir on $14^{\text {th }}$ of February 2019. According to Arceo (2016) the effects of the news provided by media platforms on general 
public perception have already been measured in developed countries but these effects are still ambiguous for developing countries. So, this study has been designed to find out whether newspaper news stories and other information creating fear effect or not?

\subsection{Objectives}

- To investigate the exposure of Pulwama attack/ incident among the newspaper readers.

- To evaluate the level of fear among the reader after Pulwama attack.

- To find out relationship between readerships fears of war and Pulwama attack.

\subsection{Research Question}

What is the level of fear of war among the Newspaper readers about Pulwama attack?

\subsection{Research Hypotheses}

H1: Readers who read newspaper stories related pulwama attack more time will have more fear of war.

H2: Exaggeration and over presentation of news stories create fear of war among readers.

\section{Review of Literature}

According to McCombs, (2018) the model that has most successfully explained the effects produced by the mass media such as newspaper and what are its relations with general public opinion and perception has been the theory of the agenda setting, which is framed in the studies of long-term effects. This theory emphasizes the power of the media to attract attention to certain issues or problems and at the same time create the frameworks for interpreting social events. The media, reporting on external reality, present to the public a list of the topics that will be the subject of public opinion and in turn shape the public perception. It is clear that the enormous growth and expansion of media institutions are today a determining element of contemporary society. Its main objective is to influence public opinion (Birkland, 2015).

Furthermore, Protess \& McCombs, (2016) highlighted the importance of the signalling influence of the news. In order to reinforce this idea it was argued that daily news tells public about the latest events and changes in that economic and political environment that is beyond public's immediate experience. But the information of the press, even those that are so tight in a tabloid newspaper, do much more, in fact, than simply pointing out the existence of important facts and issues. The editors and information directors, with their day-to-day selection and display of information, direct public's attention and influence public perception of what are the most important topics of the day. This ability to influence the relevance of public repertoire issues is what has been called the setting of the agenda by the media (DeFleur \& DeFleur, 2016).

The selection of the most important news given at the beginning of the news or news that appears on the first page of the newspapers, the size of the headlines, the extension of a news and the insistence on it one day and another day, They point to the determination of the importance of events and put them in the spotlight of public opinion and perception. It is the media that trace the clues about the importance of the daily agenda items (Birkland, 2017). As for the public, the public uses these relevant clues to organize and also decide what the most important issues that attract common attention are. Hence the information media agenda becomes the public agenda which in turn create perception or fear of a possible between two countries. In other words, highlights issues of concern are transformed into issues of major concern. This is the central thesis of the theory of agenda setting (Altheide, 2018).

Graber \& Dunaway, (2017) argued about newspaper that this media do not seek first to persuade, but when describing and specifying the external social reality, they present to the public the list of everything around what public opinion should give their opinion and debate. The study argued that the fundamental budget of the agenda setting is that people's understanding of much of social reality is modified by the media. Here, a cognitive dependence of the public on the media, both from the point of view of the "agenda" of the issues, problems and arguments, which are present in the media agenda, as of the order of importance and priority that these elements are arranged in the "agenda." The study explained that the outside world and the images public makes in their perception shape their feelings about certainty and uncertainty about a possible war. The news media, those windows open to the immense world that is beyond public's direct experience, determine the cognitive maps public make of it. This is why public opinion does not respond to the environment, but to the pseudo-environment built by the media (Protess \& McCombs, 2016).

It is clear that most of the issues that attract attention or concern public are beyond its direct personal experience and that the main source of such issues is the media. In almost all the subjects of the public repertoire, Holman, 
(2016) argued that the citizens are seen with a second-hand reality, which is structured by the information that journalists give of these facts and situations. The editors and information directors in the newspapers with their day-to-day selection and deployment of information, direct public's attention and influence public's perception of what are the most important issues of the day. This ability to influence the relevance of public repertoire issues is what has been given in calling the fixation of the agency by the media. The public draws on the clues of relevance offered by the means to organize their own perspective and identify the most important issues in public consideration. The information media perspective becomes the public perspective; it becomes public opinion and in turn shapes the perception/fear of peace or war for that matter (Lapa \& Cardoso, 2016).

\section{Theoretical Framework}

George Gerbner, presented this theory, while this theory is based on his research project in 1960s, at Annenberg School of Communications at the University of Pennsylvania called 'Cultural Indicators', where he research on the television watching and its influence on viewers (Hawkins \& Pingree, 1983).

Gerbner focuses on the long-term effects, more intense and difficult to detect, assuming that television is one of the main sources of socialization. The effects in this sense are gradual and cumulative, establishing stable guidelines for content selection and determining in relation to these behaviors, attitudes and prejudices (Birkland, 2015).

This last idea is not only reflected in the novels, but also occurs in talk show programs, where the audience is capable of generating a kind of feeling of hatred, compassion, tenderness, sadness, depending on the face of the Case to be treated A clear example is seen in the Mexican program of the Peruvian Laura, called "Laura in America" or "Cristina". Even in the news we are faced with the emotional part. For example, when we are presented with the case of natural phenomena that end the entire population of a poor country. For sample, the famous case occurred in Haiti, where entire families lost relatives and all their belongings in which houses and food are included. The news presented us the note in such a way, that we felt a feeling of compassion and help to those who at that time were already called 'brothers'. The purpose of all this happening, according to this theory, is that through the "cultivation of representations of the social world there is homology and homogeneity. That is, the audience act in the same way and propagate the prolongation of the system, and in this way the ruling class remains in power (Hetsroni, 2012).

\section{Research Methodology}

In this research study, the researchers have incorporated the quantitative research design and opted to gather numerical, objective factual data in order to provide solidified results that are backed by the empirical findings. The population of this study includes general people who are familiar with the printed media in terms of reading newspapers on a daily basis. In this study, the researcher has selected samples by using non-probability sampling technique under which purposive sampling has been applied for choosing appropriate sample for the study. Therefore, the sample size chosen for this research is around 50 including 25 readers of Daily Jang Urdu newspaper and 25 respondents of Daily Dawn English newspaper readers. The justification for choosing Daily Dawn Newspaper has the fact that it has been providing authentic information used by young people and students throughout the history. This newspaper has also been the symbol for identifying major issues pertaining in the society (Long, 2017). This is the reason that major research foundations in Pakistan have used the news forecasted by Dawn Newspaper for the purpose of analyzing social, political and international issues (Gallup and Gillani Pakistan, 2018). On the other hand, Daily Jang Newspaper is one of the oldest newspapers of Pakistan providing large amount of news content on daily basis. This has been effective in understanding not only the political issues but also social issues that are found in big and small cities of Pakistan. The data collection technique used for this study has been based on conducting surveys with the target respondents related to the study topic. The researcher developed questionnaire on the basis of literature review, variables, objectives and hypothesis. The questionnaire has 23 close-ended questions. To ensure reliability of the tool, a polite study has been done.

Table 1. Reliability Statistics about Newspaper related scale

\begin{tabular}{cc}
\hline Cronbach's Alpha & N of Items \\
\hline .785 & 9 \\
\hline
\end{tabular}

In the first stage the researcher checked the tool reliability, whereas the Newspaper related tool reliability was 0.786 which means that the scale used for survey about newspaper readers has been reliable. 


\section{Results and Findings}

Table 2. Age, gender and marital status of the respondents

\begin{tabular}{ccccccccc}
\hline & Age & \multicolumn{3}{c}{ Gender } & \multicolumn{3}{c}{ Status } \\
& $\mathrm{F}$ & $\%$ & & $\mathrm{~F}$ & $\%$ & & $\mathrm{~F}$ & $\%$ \\
\hline $20-25$ & 8 & 16.0 & Male & 39 & 78.0 & Single & 22 & 44.0 \\
$26-30$ & 22 & 44.0 & Female & 11 & 22.0 & Married & 26 & 52.0 \\
$31-35$ & 5 & 10.0 & Total & 50 & 100.0 & Others & 2 & 4.0 \\
$35-40$ & 8 & 16.0 & & & & Total & 50 & 100.0 \\
Above 40 & 7 & 14.0 & & & & & \\
Total & 50 & 100.0 & & & & & & \\
\hline
\end{tabular}

Table 2 demonstrates the age of the respondents of the newspaper reader $16 \%$ of newspaper reader aged 20 to 25 years old, $44 \%$ of 26 to 30 years, $10 \%$ of them were 31 to 35 years, $16 \%$ of 35 to 40 years and $14 \%$ of them were above 40 years old. Table also demonstrates the gender of Newspaper readers,. $78 \%$ of newspaper reader male and $22 \%$ were female. Table 2 describes the marital status of Newspaper readers. Table shows that $44 \%$ single, $52 \%$ married and $4 \%$ other respondents of Newspaper reader.

Table 3. Income of the Respondents

\begin{tabular}{ccc}
\hline & Newspaper & \\
& F & \\
\hline $10,000-15,000$ & 1 & 2.0 \\
$16,000-20,000$ & 6 & 12.0 \\
$21,000-25,000$ & 2 & 4.0 \\
$26,000-30,000$ & 8 & 16.0 \\
Above 30,000 & 30 & 60.0 \\
Jobless & 3 & 6.0 \\
Total & 50 & 100.0 \\
\hline
\end{tabular}

The results presented or tabularized in Table 3 are quite interesting to observe. This table demonstrates the income of Newspaper reader that $2 \%$ of newspaper reader income $10,000-15,000,12 \%$ of $16,000-20,000,4 \%$ of $21,000-25,000,16 \%$ of $26,000-30,000,60 \%$ of above 30,000 and $6 \%$ of jobless.

Table 4. Mostly read newspaper of the Respondents

\begin{tabular}{ccc}
\hline & Newspaper & \\
& F & $\%$ \\
\hline Jang & 25 & 50.0 \\
Dawn & 25 & 50.0 \\
\hline
\end{tabular}

Table 4 explains that $50 \%$ respondents of Jang newspaper and 50\% of Dawn readers.

Table 5. Time Consumption and place of the Respondents of Newspaper

\begin{tabular}{cccccc}
\hline & Time & & & \multicolumn{2}{c}{ Place } \\
& $\mathrm{F}$ & $\%$ & F & 21 & 42.0 \\
\hline Less than 1 hour & 26 & 52.0 & At home & 14 & 28.0 \\
$1-2$ hour & 15 & 30.0 & At office & 10 & 20.0 \\
3-4 hour & 5 & 10.0 & At shop & 5 & 10.0 \\
More than 4 hours & 4 & 8.0 & Tothers & 50 & 100.0 \\
Total & 50 & 100.0 & & & \\
\hline
\end{tabular}


Table 5 shows the time spending of reading newspaper. So, that $52 \%$ of newspaper reader spend less than 1 hour, $30 \%$ spend $1-2$ hour, $10 \%$ spend 3-4 hours and $8 \%$ spend more than 4 hours. Table demonstrates the place of respondents reading newspaper that $42 \%$ of reading newspaper at home, $28 \%$ at office, $20 \%$ reading newspaper at shop and $10 \%$ of others.

Table 6. Newspaper reader exposure to Pulwama incident and contents for reading

\begin{tabular}{cccccc}
\hline & Page & \multicolumn{3}{c}{ Contents } \\
& $\mathrm{F}$ & $\%$ & $\mathrm{~F}$ & 22 & 44.0 \\
\hline Front page & 29 & 58.0 & Headline & 14 & 28.0 \\
Second page & 3 & 6.0 & Full story & 11 & 22.0 \\
International page & 10 & 20.0 & Columns & 3 & 6.0 \\
Opinion page & 7 & 14.0 & Editorial & 50 & 100.0 \\
Others & 1 & 2.0 & Total & &
\end{tabular}

Table 6 shows respondent reading the page of newspaper that $58 \%$ reads front page, $6 \%$ reads second page, $20 \%$ reads international page, $14 \%$ reads opinion page and $2 \%$ of them reads other pages. Table 6 also demonstrates the responses of newspaper readers that $44 \%$ of readers reads headline, $28 \%$ of full story, $22 \%$ of columns and $6 \%$ of them reads editorial.

Table 7. Fear of war among respondents of newspaper

\begin{tabular}{cccccc}
\hline & Fear & & \multicolumn{3}{c}{ Fear contents } \\
& F & $\%$ & Yes & 30 & 60.0 \\
\hline Yes & 29 & 58.0 & No & 20 & 40.0 \\
No & 21 & 42.0 & Total & 50 & 100.0 \\
Total & 50 & 100.0 & &
\end{tabular}

Table 7 describes the fear of war among newspaper readers that $58 \%$ of newspaper readers responds yes and $42 \%$ of no. Table 5.19 demonstrates the situation created among respondents of newspaper reader that $60 \%$ of newspaper reader responds yes and $40 \%$ no.

Table 8. Repetition of news stories, blaming contents and presentation of LOC situation leads towards fear of war

\begin{tabular}{ccccccc}
\hline & Repetition & \multicolumn{3}{c}{ BOC } \\
& $\mathrm{F}$ & $\%$ & $\mathrm{~F}$ & $\%$ & $\mathrm{~F}$ & $\%$ \\
\hline Strongly Disagree & 5 & 10.0 & 3 & 6.0 & & \\
Disagree & 12 & 24.0 & 11 & 22.0 & 6 & 12.0 \\
Neutral & 10 & 20.0 & 8 & 16.0 & 6 & 12.0 \\
Agree & 18 & 36.0 & 19 & 38.0 & 26 & 52.0 \\
Strongly Agree & 5 & 10.0 & 9 & 18.0 & 12 & 24.0 \\
Total & 50 & 100.0 & 50 & 100.0 & 50 & 100.0 \\
\hline
\end{tabular}

Table 8 illustrates the comparison of the respondents regarding the repletion of news stories creation fear of war that $36 \%$ of newspaper reader were agreed with notion that repeatedly presentation of information creating fear of war among the audience, While, $24 \%$ of newspaper reader were disagreed. Table also illustrates the comparison of the respondents regarding blaming content in news stories creating fear of war that $38 \%$ of newspaper reader were agreed, Whereas, $22 \%$ of newspaper reader were disagreed. Table shows the opinion of the respondents regarding LOC situation in news stories creation fear of war that $52 \%$ of newspaper reader were agreed with belief that presentation of LoC situation creating fear of war. Further, 12\% of newspaper readers were disagreed. 
Table 9. Presentation of news in exaggerated form and biased information leads towards fear of war

\begin{tabular}{ccccc} 
& Exaggeration & \multicolumn{3}{c}{ Biased information } \\
& $\mathrm{F}$ & $\%$ & $\mathrm{~F}$ & 4.0 \\
\hline Strongly Disagree & 1 & 2.0 & 2 & 22.0 \\
Disagree & 9 & 18.0 & 11 & 16.0 \\
Neutral & 8 & 16.0 & 8 & 34.0 \\
Agree & 25 & 50.0 & 17 & 24.0 \\
Strongly Agree & 7 & 14.0 & 12 & 100.0 \\
Total & 50 & 100.0 & 50 & \\
\hline
\end{tabular}

Table 9 elaborated the comparison of respondents regarding presentation of news in exaggerated creating fear of war that $50 \%$ of newspaper readers were agreed and $18 \%$ of newspaper readers were disagreed with notion of news stories presentation in exaggerated form. Table also presents the belief of respondents regarding biased information in news content creating fear of war that $34 \%$ newspaper reader and $22 \%$ of newspaper reader were disagreed.

Table 10. Manipulation in news stories, propaganda contents and negative portrayal of Pakistan leads toward fear of war

\begin{tabular}{ccccccc}
\hline & Newspaper & & TV & Social Media \\
& F & $\%$ & F & $\%$ & F & $\%$ \\
\hline Strongly Disagree & 1 & 2.0 & 2 & 4.0 & 2 & 4.0 \\
Disagree & 17 & 34.0 & 5 & 10.0 & 9 & 18.0 \\
Neutral & 7 & 14.0 & 7 & 14.0 & 3 & 6.0 \\
Agree & 20 & 40.0 & 25 & 50.0 & 24 & 48.0 \\
Strongly Agree & 5 & 10.0 & 11 & 22.0 & 12 & 24.0 \\
Total & 50 & 100.0 & 50 & 100.0 & 50 & 100.0 \\
\hline
\end{tabular}

The researcher further investigated from the respondents whether or not the manipulative content affects their state of mind in terms of fear of war. It has been found from the analysis that $34 \%$ of newspaper reader disagreed and $40 \%$ of them agreed to the notion. The findings imply that fear of war is attributed to the manipulative content present to some extent. $50 \%$ of newspaper reader were agreed, while, $10 \%$ of them were disagreed. It has been found that $48 \%$ of newspaper reader lies in the category of agreement; however, $18 \%$ of newspaper reader negated the opinion.

Table 11. Comparison of dominancy in terms of military and nuclear power leads toward fear of war

\begin{tabular}{ccc}
\hline & F & $\%$ \\
\hline Strongly Disagree & 4 & 8.0 \\
Disagree & 2 & 4.0 \\
Neutral & 8 & 16.0 \\
Agree & 11 & 22.0 \\
Strongly Agree & 25 & 50.0 \\
Total & 50 & 100.0 \\
\hline
\end{tabular}

In the case of the comparison of the dominancy in terms of military personnel or specifically nuclear power, the prospects of fear of war increased. In this case, it has been found that $72 \%$ of newspaper reader answered in the category of agreement and strongly agreement. In addition, it has been further found that $12 \%$ of them were disagreed cumulatively.

\section{Hypothesis Testing}

H1: Readers who read newspaper stories related pulwama attack more time will have more fear of war. 
Table 12. Correlation between Watching Time and Fear of War

\begin{tabular}{|c|c|c|c|c|}
\hline \multicolumn{5}{|c|}{ Correlations } \\
\hline & & & How often do you read newspaper? & Fear \\
\hline \multirow{6}{*}{ Spearman's rho } & \multirow{3}{*}{$\begin{array}{c}\text { How often do you read } \\
\text { newspaper? }\end{array}$} & Correlation Coefficient & 1.000 & .112 \\
\hline & & Sig. (2-tailed) & . & .003 \\
\hline & & $\mathrm{N}$ & 50 & 50 \\
\hline & \multirow{3}{*}{ Fear } & Correlation Coefficient & .112 & 1.000 \\
\hline & & Sig. (2-tailed) & .003 & . \\
\hline & & $\mathrm{N}$ & 50 & 50 \\
\hline
\end{tabular}

The researchers have applied Spearman's rho correlation which is a non-parametric test because of the data's distribution. Considering this fact, the frequency of reading time is significantly associated with the fear of war. However, the association is computed was $0.113, p=.003$ which is positive and this implies that with the increment in the newspaper reading time, the fear of the war in the readers would also increase with a relatively lower magnitude.

H2: Exaggeration and over presentation of news stories create fear of war among readers.

Table 13. Correlation Between Watching Time and Fear of War

\begin{tabular}{|c|c|c|c|c|c|c|c|}
\hline \multicolumn{8}{|c|}{ Do you think that the newspaper stories lead you towards fear of war? $*$ News stories presented in exaggerated form about } \\
\hline Count & & & & & & & \\
\hline & & \multicolumn{5}{|c|}{$\begin{array}{l}\text { News stories presented in exaggerated form about Pulwama incident leads me } \\
\text { towards fear of war? }\end{array}$} & \multirow[t]{2}{*}{ Total } \\
\hline & & Strongly Disagree & Disagree & Neutral & Agree & Strongly Agree & \\
\hline Do you think that the & Yes & 0 & 3 & 4 & 15 & 7 & 29 \\
\hline $\begin{array}{c}\text { newspaper stories lead } \\
\text { you towards fear of war? }\end{array}$ & No & 1 & 6 & 4 & 10 & 0 & 21 \\
\hline Total & & 1 & 9 & 8 & 25 & 7 & 50 \\
\hline
\end{tabular}

Do you think that the newspaper stories lead you towards fear of war? * Repeatedly reading the news stories about Pulwama leads me towards fear of war Crosstabulation

Count

\begin{tabular}{|c|c|c|c|c|c|c|c|}
\hline & & \multicolumn{5}{|c|}{$\begin{array}{l}\text { Repeatedly reading the news stories about Pulwama leads me towards fear of } \\
\text { war }\end{array}$} & \multirow[t]{2}{*}{ Total } \\
\hline & & Strongly Disagree & Disagree & Neutral & Agree & Strongly Agree & \\
\hline Do you think that the & Yes & 3 & 3 & 5 & 13 & 5 & 29 \\
\hline $\begin{array}{l}\text { newspaper stories lead } \\
\text { you towards fear of war? }\end{array}$ & No & 2 & 9 & 5 & 5 & 0 & 21 \\
\hline Total & & 5 & 12 & 10 & 18 & 5 & 50 \\
\hline
\end{tabular}

The cross tabulation analyses supported the $\mathrm{H} 2$ that news related Pulwama attack presented in exaggerated and repeatedly which created fear of war among them. Majority of the readers showed agreement and strongly agreement on the notion. The results of the study supported the H2.

\section{Discussion and Conclusions}

The first objective of the study was to investigate the exposure of Pulwama incident amongst the newspaper readers, and it has been found that level of exposure of the Pulwama incident amongst the media consumers was quite high, as indicated by the results of this study. This was primarily contributed to by the context of India namely that Pakistanis almost always, as also highlighted by Rao (2019), closely follow any such incidents in India; as evident from history of Pakistan and India, these countries have had a bitter relationship and hence, no chance or opportunity of defaming the other in the international community is left un-availed. Under these 
circumstances, right when the Pulwama incident took place, the Pakistanis had anticipated that there will be some sort of action against Pakistan. As such, the significance of the media reporting and the creation of awareness amongst the local populace was hence important in two ways. Firstly, the role of the media was to spread word about the happening in India so that (a) information symmetry is created amongst the masses, and (b) the nation unites on a single platform against any such action by India of a similar nature. Secondly, the more important role of the media was to take the international community in loop so as to absolutely deny the involvement of Pakistan in such a kind of attack. Hence, the local population of the country was very much exposed to the news.

The study was found the relationship between the fear of war and news content amongst the readers in the context of exposure to Pulwama attack, and the results of this study have found out that the relationship between a thought of war and the news content is positive, which means that the phrasing of the news content significantly influenced the sentiment of the masses so much so that it apparently seemed that an all-out war of Pakistan and India will soon break out. However, in the light of the preceding discussion, it may be said that this was the relationship of news content with only the thought of war; the research study found no evidence as to whether the Pakistani news consumer were afraid of war or had a fear of the same; the real issue was that of effectively planning to finalize the stance of the nation on India's Pulwama incident.

\section{Recommendation to Newspapers Publishers}

The recommendation is that of sharing the news stories as news stories. Experts such as Rao (2019) have argued that there is an increasing trend of manipulating, through words, the minds of the rational consumer of the news stories. In this way, an attempt is made to create an atmosphere of bias amongst the countrymen. This attitude of the news channels, especially the electronic media industry, must be curtailed, due to the reason such a form of bias creates lots of misunderstandings on part of the masses (Feyaz, 2019), and also much often results in the creation of a divide amongst the people of the country.

\section{References}

Altheide, D. L. (2018). Creating fear: News and the construction of crisis. Routledge.

Arceo, E., Hanna, R., \& Oliva, P. (2016). Does the effect of pollution on infant mortality differ between developing and developed countries? Evidence from Mexico City. The Economic Journal, 126(591), 257-280. https://doi.org/10.1111/ecoj.12273

Birkland, T. A. (2015). An introduction to the policy process: Theories, concepts, and models of public policy making. Routledge.

Bjørkdahl, K., \& Carlsen, B. (2017). Fear of the Fear of the Flu: Assumptions About Media Effects in the 2009 Pandemic. Science Communication, 39(3), 358-381. https://doi.org/10.1177\%2F1075547017709792

DeFleur, M. L., \& DeFleur, M. H. (2016). Mass communication theories: Explaining origins, processes, and effects. Routledge. Retrieved from athttps://aejmc.us/icd/wp-content/uploads/sites/11/2019/10/Jatin-Srivast ava_Grad-Seminar-in-Mass-comm-theory.pdf

Feyyaz, M. (2019). Contextualizing the Pulwama Attack in Kashmir-A Perspective from Pakistan. Perspectives on Terrorism, 13(2), 69-74. https://www.jstor.org/stable/26626867

Gallup \& Gillani Pakistan. (2018). A monthly series from Gallup \&Gilani Pakistan Media Research Wing looking at around 3000 Newspaper columns and editorials. Gilani Research Foundation.

Graber, D. A., \& Dunaway, J. (2017). Mass media and American politics. Cq Press.

Hawkins, R. P., \& Pingree, S. (1983). Televisions influence on social reality.

Hetsroni, A. (2012). Associations between television viewing and love styles: an interpretation using cultivation theory. Psychological reports, 110(1), 35-50. https://doi.org/10.2466\%2F17.PR0.110.1.35-50

Holman, B. (2016). The Next War in the Air: Britain's Fear of the Bomber, 1908-1941. Routledge. https://www.dawn.com/news/1464153

Lapa, T., \& Cardoso, G., (2016). (Social) Media isn't the message, networked people are: calls for protest through social media. Observatorio (OBS*), 10(ESPECIAL), 202-219.

Long, R. (2017). Dawn Delhi I: Genesis of a Newspaper. Retrieved from https://www.dawn.com/news/1354278

McCombs, M. (2018). Setting the agenda: Mass media and public opinion. John Wiley \& Sons.

Potter, W. J. (2014). A critical analysis of cultivation theory. Journal of communication, 64(6), 1015-1036. 
https://doi.org/10.1111/jcom. 12128

Protess, D., \& McCombs, M. E. (2016). Agenda setting: Readings on media, public opinion, and policymaking. Routledge.

Rao, H. N. (2019). The role of new media in political campaigns: A case study of social media campaigning for the 2019 general elections. Asian Journal of Multidimensional Research (AJMR), 8(4), 228-240. http://dx.doi.org/10.5958/2278-4853.2019.00153.8

Tuan, Y. F. (2013). Landscapes of fear. U of Minnesota Press.

\section{Acknowledgment}

I owe much my especial thanks to, Nimra Gul and Dr.Fazal Rahim Khan, for their candid form of support; encouragement; guidance and ability to facilitate me from initial conceptualization to the last word of the final draft of this Article. Another academic eminence who has provided the same sort of fundamental support and encouragement in the revision of this article, and who I owe a great deal of gratitude, is Dr.Faiza Latif.

\section{Copyrights}

Copyright for this article is retained by the author(s), with first publication rights granted to the journal.

This is an open-access article distributed under the terms and conditions of the Creative Commons Attribution license (http://creativecommons.org/licenses/by/4.0/). 